YEARBOOK

of ANTITRUST

and REGULATORY

STUDIES

www.yars.wz.uw.edu.pl
Peer-reviewed scientific periodical, focusing on legal and economic issues of antitrust and regulation. Creative Commons Attribution-No Derivative Works 3.0 Poland License.

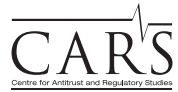

Centre for Antitrust and Regulatory Studies, University of Warsaw, Faculty of Management www.cars.wZ.uw.edu.pl

\title{
Independence of National Competition Authorities - Problem Solved by Directive 2019/1? Example of the Antimonopoly Office of the Slovak Republic ${ }^{*}$
}

\author{
by
}

Mária T. Patakyová**

\section{CONTENTS}

I. Introduction

II. The notion of 'independence'

1. Concepts

2. View of the scholars on independence of regulatory bodies 2.1. Necessity of independence

2.2. Elements of independence

III. Independence of National Competition Authorities - the status quo regarding the AMO

IV. Independence of National Competition Authorities in the light of Directive 2019/1

1. The requirements pursuant to Directive 2019/1

2. What shall be amended in the Act on Competition?

V. Conclusion

\section{Abstract}

This paper analyses the independence of National Competition Authorities under legislation before Directive 2019/1 and after Directive 2019/1. The aim of the paper is to find out whether Directive 2019/1 addresses the problem of independence

* This article was supported from a Grant project of "Agentúra na podporu výskumu a vývoja v rámci projektu č. APVV-17-0641 "Zefektívnenie právnej úpravy verejného obstarávania a jej aplikácie v kontexte práva Európskej únie"."

** Assistant professor at Institute of European Law, Faculty of Law, Comenius University in Bratislava, Slovakia. Maria.patakyova2@flaw.uniba.sk. Article received: 10 June 2019; accepted: 1 July 2019. 
properly or not. In order to answer the question, it discusses what does the term 'independence' actually mean, especially in the view of scholars. Several aspects of independence are identified. Subsequently, this paper zooms in on what are current imperfections when it comes to the independence of National Competition Authorities. The Antimonopoly Office of the Slovak Republic (AMO) is discussed in particular. The paper then finds out what are the requirements set out by Directive 2019/1 and whether these requirements address the imperfection identified above. The paper confirms that these imperfections are covered only partially.

\section{Resumé}

Cette article analyse l'indépendance des autorités nationales de concurrence selon la législation avant Directive 1/2019 et après Directive 1/2019. Le but de cet article est de trouver la réponse de la question si Directive 1/2019 dénoue le problème de l'indépendance. Pour répondre à cette question, l'article analyse la notion de l'indépendance, surtout d'après des académiciens. Plusieurs aspects de l'indépendance sont identifiés. Puis, l'article s'oriente vers des imperfections de l'indépendance des autorités nationales de concurrence. Lautorité anti-monopolistique de la République Slovaque est analysée particulièrement. Le document examine ensuite quelles sont les conditions fixées par la Directive 2019/1 et si ces conditions répondent aux imperfections identifiées ci-dessus. Larticle confirme que ces imperfections ne sont que partiellement couvertes.

Key words: Independence, National Competition Authorities, Antimonopoly Office of the Slovak Republic, institutional design, Directive 2019/1.

JEL: K21, K23

\section{Introduction}

Since Regulation 1/2003 ${ }^{1}$ came into effect, National Competition Authorities (hereinafter: NCAs) have played a vital role in the enforcement of European competition law. The decentralised application of Articles 101 and 102 TFEU put the burden on the shoulders of the Members States of the EU (hereinafter: Member States), as they should secure effective enforcement. Regulation 1/2003 itself gives strong powers to NCAs, as they may require that an infringement be brought to an end, order interim measures, accept commitments and impose fines, periodic penalty payments or any other penalty provided for in their national law. ${ }^{2}$

1 Council Regulation (EC) No 1/2003 of 16 December 2002 on the implementation of the rules on competition laid down in Articles 81 and 82 of the Treaty ("Regulation 1/2003").

2 Article 5 of Regulation 1/2003. 
Although regulatory bodies, such as NCAs, have strong powers at their disposal, they would be of no good if the NCAs cannot use them when appropriate and in a manner that is appropriate. Therefore, the independence of such bodies is essential.

It is perfectly acknowledgeable that the notion of independence is not understood in unison. There are many ways how to assess the meaning of independence and what does it require. However, we have chosen to analyse the views of scholars who analysed regulatory bodies, ${ }^{3}$ such as NCAs, the Commission or sector regulators. ${ }^{4}$ As long as the assessment of the notion of independence is only a means how to get to the core analysis of this paper, and not an end in itself, we dare to consider such assessment to be sufficient.

In order to reach a more accurate analysis, we have chosen one particular NCA on which the assessment of independence is performed. ${ }^{5}$ The Slovak NCA - the Antimonopoly Office of the Slovak Republic (hereinafter: AMO) is the institution which is tasked to enforce competition law in the Slovak Republic. The paper focuses primarily on de iure independence in light of Act No. 136/2001 Coll. on protection of competition in its current ${ }^{6}$ version (hereinafter: Act on Competition) and in light of Regulation 1/2003. When appropriate, it tries to zoom in on de facto independence of this NCA as well.

In December 2018, the European Parliament and the Council adopted Directive 2019/1. ${ }^{7}$ One of the objectives of Directive 2019/1 is to ensure that NCAs have guarantees of independence. ${ }^{8}$ Therefore, this paper examines whether Directive 2019/1 fulfils this objective. In order to ascertain whether this is the case, this paper examines what might be the imperfections of securing the independence of the AMO under law de lege lata, and whether these imperfections are solved by Directive 2019/1.

Thus, the paper is organised as follows. First, the term of 'independence' is addressed. The view of the scholars, supplemented by decisions of the CJEU, is discussed. Several aspects of independence are identified. Second, the situation

${ }^{3}$ For the purposes of this paper, terms institution, body, authority are used predominantly as synonyms.

${ }^{4}$ Other ways how to understand the meaning of independence would be to see requirements and suggestions of international organisations (such as OECD) or various NGOs; to exhaustively analyse the requirements deriving from judgements of national or European courts.

5 The comparison with other jurisdictions is not conducted and it is deliberately out of scope of this paper, unless it is referred to a paper of scholars who conducted such comparison. The outcomes of such comparison are used and dully referred.

${ }^{6}$ Hence, Act on Competition which is in effect in June 2019 is discussed here.

7 Directive (EU) 2019/1 of the European Parliament and of the Council of 11 December 2018 to empower the competition authorities of the Member States to be more effective enforcers and to ensure the proper functioning of the internal market ("Directive 2019/1").

${ }^{8}$ Recital 3 of Directive 2019/1. 
of the AMO under Regulation 1/2003 and under the Act on Competition is outlined, whereas several shortcomings of the current stage of independence are identified. Third, independence under Directive 2019/1 is presented, with particular focus on specific obligations which shall be fulfilled by Member States when designing NCAs. Subsequently, the shortcomings identified in relation to the AMO are matched with the specific obligations under Directive 2019/1. Last but not least, the conclusion answers the question on whether the problem of independence is solved by Directive 2019/1.

\section{The notion of 'independence'}

\section{Concepts}

'Independence' does not refer to one concept only. As a matter of fact, there are several understandings of independence. Various concepts were presented by scholars as well as relevant institutions, organisations or think-tanks. We will now briefly look into the concepts presented by scholars in order to establish what is understood under the notion of independence.

It shall be noted in the beginning that there are two basic distinctions in the approach. The first one is related to de iure and de facto independence. The former refers to independence as it flows from the legal norms. Therefore, an institution is independent if it has legal safeguards which separate the institution from influences. Some authors use the notion 'formal independence' (Alves, Capiau and Sinclair, 2015, p. 16). De facto independence relates to the functioning of the institution in the real world. If we deal with de facto independence, we do not explore the legal norms only but also examine influences on the institutions which are not presumed by the wording of the legal norms. Arguably, the level of de facto independence might be more decisive (Winter, 2013, p. 166).

The second distinction relates to political and functional independence (Zemanovičvá, 2017, p. 49). The former is rather self-explanatory. It asks the question on how can politicians, the respective government in particular, influence the institution. The latter refers to the separation of the institution from businesses - market players (Cseres, 2013, p. 37). If an institution should control acts of businesses, in that case it is inevitable to safeguard the independence of the institution from these regulated subjects. Thus, functional and political independence prevents the authority from achieving political or business goals which are not related to competition policy (Alves, Capiau and Sinclair, 2015, p. 15). Nowadays, both elements are often required (Ottow, 2013, p. 140). 


\section{View of the scholars on independence of regulatory bodies}

The question of independence has been a research subject of many scholars for decades (Cseres, 2013, p. 10). Several of them have focused particularly on competition authorities. Arguably, the approach is similar when it comes to other regulatory bodies, such as sector regulators. Consequently, we will now look into the studies of various authors who have zoomed in on independence of competition authorities and of other regulators.

\subsection{Necessity of independence}

It is accepted in general that competition authorities should be independent (Alves, Capiau and Sinclair, 2015, p. 14-15). ${ }^{9}$ This flows from the fact that effective law enforcement is conditional upon a proper set of procedural and institutional rules (Cseres, 2013, p. 9). In other words, no matter how well-established substantive rules are, they are always brought to life by procedural rules employed by an institution (when we consider public enforcement).

Van de Gronden and de Vries looked into independence of competition authorities in the EU (2006). Before looking into elements which they considered to be important for the independence of an institution, it is of particular interest to discuss to what an extent these authors considered independence of competition authorities as a necessity. It flows from their discussion that due to the fact that competition policy is only one of the legitimate policies of a State (the EU in this case), reasons of coherence require that competition policy is created and enforced together with other policies. Furthermore, the umbrella of democratic control of a parliament cannot be omitted too. (Van de Gronden and de Vries, 2006, pp. 65-66).

Although these considerations were presented in relation to a possible creation of a separate EU Competition agency, they may be applied to existing competition authorities mutatis mutandis. There is always a need to find a balance between policy considerations and discretion for independent authorities (Ottow, 2013, p. 155). An idea of having a completely independent authority would inevitable mean that this authority would be free to act arbitrarily. This is definitely not welcome, especially regarding strong powers in the hands of competition authorities. ${ }^{10}$

${ }^{9}$ It shall be stressed that independence does not necessary mean dividing regulators to narrow-focused institutions. For example, it is not always beneficial to separate the protection of competition and protection of consumers (Cseres, 2013, pp. 12-13). This is particularly true nowadays, when internet giants create situations require complex regulatory approach.

10 To mention but one example, the possibility to conduct dawn raids is a strong interference into the rights of undertakings. To this end, see Patakyová (2019). 
Therefore, what might be derived from the considerations above is that independence should not refer to a total separation of other bodies and policies. It shall rather refer to a possibility of the respective institution to collect the necessary information, to act when there is a need to act and in a manner that is appropriate (Alves, Capiau and Sinclair, 2015, p. 15), (Winter, 2013, p. 160).

\subsection{Elements of independence}

The first element already suggested above is related to accountability. Each regulatory body, no matter how much it needs to be politically and functionally independent, must always be responsible to a democratic assembly. Due to the fact that the selection of persons to regulatory bodies by public election would not seem feasible, these types of institutions are usually accountable to the respective parliament. It shall be stressed at this point that parliaments and governments are interconnected in many States. In practice, the term accountability is usually connected to an annual report being presented to the parliament or the appearance of the head of the institution at stake for a hearing in the parliament or one of its committees (Alves, Capiau and Sinclair, 2015, p. 17). ${ }^{11}$

However, accountability may be increased also by visibility of the institution and the awareness of the public of the policy the institution pursues. This is related to the fact that there are many forms of accountability, such as accountability to politicians, to the market or to the judiciary (Cseres, 2013, pp. 40-41), (Black, 2012, p. 4).

Apart from democratic accountability, one cannot underestimate the impact of judicial accountability (Alves, Capiau and Sinclair, 2015, p. 17). This is related to the fact that each decision of a regulatory institution is, as a matter of rule, subject to possible judicial review. ${ }^{12}$ This is inevitably

11 This prima facie contradiction was already recognised (and solved) by the CJEU. It was held in the case C-518/07 European Commission v Federal Republic of Germany [2010] I-01885, paras 39-46 that principle of democracy is observed by the EU law and, therefore, it is not precluded to have parliamentary influence over regulatory bodies to certain extent, for example, by having the management of supervisory authorities to be appointed by the parliament or the government; or by reporting of activities to the parliament.

However, it flows from C-614/10 European Commission v Republic of Austria [2012], paras 62-63, that if the government has too broad right to information, this might be understood as indirect influence on the institution.

12 Notwithstanding the role of national courts as appeal bodies to the decisions of national competition authorities, national courts can also enforce competition law on their own. This is done mainly based on an action for damages, which may either follow a decision of a national competition authority on infringement of competition law, or it may be an action on its own, so called stand-alone action (Ezarchi, 2016, p. 595). 
related to fundamental rights of persons who are affected by the decision, ${ }^{13}$ however, from a broader perspective, judicial review also guarantees that the institution will not pursue other interests than the ones which are supposed to be pursued.

In relation to German, UK and Dutch competition authorities, which were analysed by Van de Gronden and de Vries, their internal design was considered as particularly important (2006). It is claimed that a collective decision-making body reinforced independence of competition authorities, as the outcome of proceedings does not depend on one person only. Likewise, it is looked upon favourably when competition authorities have two bodies at the head of the institution, as it allows checks and balances to be implemented. (Van de Gronden and de Vries, 2006, pp. 62-63).

In general, de iure independence is strengthened by legal and structural separation from government and ministries, which is essential. (Alves, Capiau and Sinclair, 2015, p. 16). However, political independence cannot be absolute. Van de Gronden and de Vries conclude that none of the jurisdictions they analysed had safeguarded complete political independence. This is so due to the fact that, although interventions into ongoing investigations are seen as a questionable power of the government, incorporation of long-term political considerations into competition policy is rather acceptable. ${ }^{14}$ Therefore, general instructions of the respective Minister are allowed pursuant to both German and Dutch law. The UK law even accepts interventions in individual cases albeit only in certain situations. (Van de Gronden and de Vries, 2006, pp. 63-65).

Authors Alves, Capiau and Sinclair pointed out that de facto independence depended to a great extent on the person who is the head of the particular authority (2015, p. 16). This is certainly dependent on the appointment procedure of the head of the authority and on the criteria for the position, which may be established by legal rules. Likewise, the independence of the authority is strengthened when explicit and strict grounds for dismissal are established (Alves, Capiau and Sinclair, 2015, p. 16, 21). ${ }^{15}$ Were these requirements lacking, the government (or another body entitled to dismiss the head of the institution) would be in a position to easily remove the person if he/she would commence to take steps against the will of the government.

13 To this end, see Patakyová (2019).

14 The differentiation between general instructions and instructions addressing concrete situations has been highlighted by other authors too, for instance by Ottow (2013, p. 155).

15 I tis quite appalling that in some Member States of the EU there are no criteria laid down for the appointment of head or board of NCAs, However, for large majority of NCAs, the tenure for head of NCAs and their board members is fixed and explicit rules on their dismissal are adopted (Alves, Capiau, Sinclair, 2015, p. 21). 
Therefore, any dismissal outside of the strictly designated and objective reasons might threaten the independence of the institution. ${ }^{16}$

Each institution is, as a matter of fact, only a gathering of persons working for the institution, supported by its material resources. Therefore, if one would like to explore the functioning of an institution, it is necessary to see 'behind the veil' of the institution. Therefore, de facto independence is largely related to the personal and material background of the respective institution (Alves, Capiau and Sinclair, 2015, p. 22). Although it cannot be assumed that the more persons and funds an institution has at its disposal, the more independent it is; there is undoubtedly a relationship between these two factors, though probably not linear. (Alves, Capiau and Sinclair, 2015, p. 16, 17, 22). The question of whether authorities have a separate budget as well as freedom in employment of their own staff is of utmost importance (Alves, Capiau and Sinclair, 2015, p. 22). ${ }^{17}$

It is interesting to note that many scholars point towards rules on the conflict of interest. However, they usually connect them with the head of the institution. (Alves, Capiau and Sinclair, 2015, p. 21). However, conflicts of interests of ordinary employees of an authority are likewise severe. (Winter, 2013, p. 160).

Nevertheless, due to the limitation of the scope of this paper, we will not deal with the issue of a conflict of interest in further detail. The questions of persons and funds would be addressed only partially. The following parts of this paper mainly focus on accountability, internal design, separation from government and the appointment and dismissal of head(s) and members of appeal bodies of the chosen NCA.

\section{Independence of national competition authorities - the status quo regarding the AMO}

Nowadays, procedural aspects of competition law enforcement, when it comes to Articles 101 and 102 TFEU, are governed by Regulation 1/2003. This act strengthened the position of NCAs, which can now be characterised as the backbone of EU competition law enforcement (Małobęcka-Szwast, 2018, p. 26; Kalesná, 2012, p. 5). They can apply Articles 101 and 102 TFEU to their full extent (Craig, de Búrca, 2015, p. 1049). Pursuant to Article 5 of Regulation 1/2003, NCAs are empowered to impose penalties, to accept commitments, to order interim measures, to require that a breach of

\footnotetext{
16 To this end, see for instance C-288/12 European Commission v Hungary [2014], para 59.

17 Large majority of NCAs have a separate budget allocation and they employ their own staff (Alves, Capiau, Sinclair, 2015, p. 22).
} 
competition rules is brought to an end, or to declare that there are no grounds for action. The latter does not mean the same as to declare that competition law was not infringed by a particular practice of an undertaking, as established by the case-law ${ }^{18}$ of the CJEU (Jones, Sufrin, 2016, p. 1013), (Whish, Bailey, 2012, p. 252).

Despite the broad powers and important position of NCAs, it is of utmost interest that independence as such is mentioned only once in Regulation 1/2003, in particular in Recital 31. Even this provision is not related to institutional independence of NCAs. The provision is related to an interruption of a limitation period by 'procedural steps taken independently by the competition authority of a Member State'. ${ }^{19}$ None the less, Article 35 para. 1 of Regulation 1/2003 expressly states that application of Articles 101 and 102 TFEU shall be safeguarded. Each NCA should be capable of fulfilling the tasks Regulation 1/2003 prescribes (Jones, Sufrin, 2016, p. 1014). As stated above, it may be assumed that the level of independence of a NCA influences the level of effective enforcement of competition rules. Hence, independence of NCAs is implicitly required by Regulation 1/2003. ${ }^{20}$

Yet, as observed by scholars mentioned above, independence of NCAs is not perfectly safeguarded in all Member States. Let us now discuss how the Slovak NCA, the AMO, stands when it comes to these issues.

Regarding democratic accountability, the AMO is part of the executive power. The AMO shall present a report to the government once per year and also always when asked so by the government. It is interesting that the report is not presented to the parliament. However, the government is accountable to the parliament. In relation to the influence of such reports on independence, it was presented above that an annual reporting obligation is accepted in general.

Taking judicial accountability under consideration, it shall be stressed that the Slovak judicial system is relatively open to review of administrative acts and decisions (Patakyova, 2019, p. 150). Protection of individual rights is guaranteed and, by the same token, courts oversee whether a decision or an act of the AMO was based on objective evidence or not. If the latter was the case, it might suggest that the AMO did not act independently, but perhaps

18 In particular, it was established in the case C-375/09 Prezes Urzędu Ochrony Konkurencji i Konsumentów v Tele2 Polska sp. z o.o., devenue Netia SA [2011] I-0305.

19 Regulation 1/2003, Recital 31.

20 Pace argues that this provision requires NCAs to be allocated with staff and resources at a sufficient level $(2015$, p. 252). However, we may argue that this provision requires not only this part of independence to be observed, but it requires NCAs to be independent in its entirety. This is so due to the fact that, as stated already, the level of independence of an NCA influences the level of its performance. 
on a political order. Yet, when it comes to AMO's inactivity, this cannot be effectively superintended by courts. The AMO, as well as the Commission, is not obliged to act - instead, it is entitled to act. Therefore, even if the AMO deliberately does not commence proceedings against an undertaking that infringes competition law, courts cannot punish the AMO for its omission to act. ${ }^{21}$ Although it appears that the independence of AMO is diminished by this, it shall be highlighted that this is a common feature of competition law enforcement. If competition authorities were obliged to act under all circumstances, it would mean that they could not set enforcement priorities and that their capacity would be spread too thinly across too many cases without the possibility to conduct a sufficiently deep analysis. ${ }^{22}$

The head of the AMO is the president (predseda). He is appointed by the President of the Slovak Republic based on a nomination of the Slovak government. At this point we can observe that the government plays a vital role in the selection process of the president of the AMO, which may be seen negatively. Moreover, the Act on Competition ${ }^{23}$ does not require a special procedure for the selection, such as a public hearing, nor does it contain a transparent selection procedure (Zemanovičová, 2017, p. 49). It is interesting that there is also no regulation of who can nominate the candidates to the government. Therefore, the nomination of the head of the AMO is in the hands of political parties which form the government.

Political influence cannot be excluded in relation to the current president of the AMO, Mr. Tibor Menyhart. There are voices suggesting his close relationship to a person behind one governing party, Most-Híd. Mr. Menyhart confirmed that he knew the person and that the person was his superior for five years in his previous position. Yet, Mr. Menyhart strongly denied any influence of that person on the AMO (Kováč, 2016a).

In any case, the government is not the alpha and omega of the whole process. It is positive that there is another subject involved in the appointment process. The President of the Slovak Republic is a person elected directly by citizens in a separate election. As the President of the Slovak Republic and

21 On the other hand, it shall be stressed that other undertakings are not defenceless when they see that there is an inactivity of the AMO. Pursuant to Act No. 350/2016 Coll. on certain rules on application of rights to damages caused by infringement of competition law (which implemented Directive 2014/104/EU of the European Parliament and of the Council of 26 November 2014 on certain rules governing actions for damages under national law for infringements of the competition law provisions of the Member States and of the European Union), private enforcement of competition law is well possible within the Member States of the EU. To this end, see, for instance, Kalesná (2018).

22 In any case, it may be difficult to distinguish between legitimate refusal to investigate on the one hand, and politically motivated refusal to investigate on the other.

23 The relevant provision of Act of Competition in this relation is Section 15. 
the parliament (which forms the government) are elected separately, they may be from different sides of the political spectrum. This may increase the independence of the president of the AMO.

Since the Slovak Republic is a parliamentary democracy (Ottová, 2006, p. 143), the position of the President of the Slovak Republic is rather weak, even though he/she has his/her mandate directly from citizens. There has been quite an unclear decisional practice of the Constitutional Court of the Slovak Republic on the question whether the President of the Slovak Republic may refuse to nominate a person. It is not appropriate to analyse these issue here, suffice it to say that the President of the Slovak Republic has limited powers in this regard.

Zooming in on the requirements for the president of the AMO, one cannot overlook the missing criteria on expertise, experience or personal integrity in the Act on Competition. Certain further requirements for the president of the AMO's integrity are laid down in a separate piece of legislation. Pursuant to Section 15 para 5 of the Act on Competition, the function of the president of the AMO is incompatible with functions and activities pursuant to the Constitutional Act No. 357/2004 Coll. on Protection of Public Interest in Exercise of Function of Public Functionaries, as amended (hereinafter: Constitutional Act on Protection of Public Interest). These includes, inter alia, being part of a statutory, managing, control or supervisory body of a legal person established for business purposes or exercising of entrepreneurial activities. ${ }^{24}$ Article 4 para. 1 of the Constitutional Act on Protection of Public Interest obliges public functionaries to protect public interest during their term. They shall refrain from all actions which might be against this Constitutional Act, for example to use their functions or information they obtain for the benefit of themselves or of other persons. This strengthens the functional independence of the head of AMO. ${ }^{25}$ On the other hand, from the practical perspective, this Constitutional Act is not enforced very well, even though there are mechanisms and sanctions prescribed therein. ${ }^{26}$

Moving forward, it is surprising that there are no professional criteria for the position of the head of AMO. Anyone who is a citizen of the Slovak

24 This is established in Art. 5 para 2 of Constitutional Act on Protection of Public Interest.

25 For the sake of completeness, it shall be noted that the functional independence is strengthened also by the fact that the head of the AMO is partially limited in exercise of certain functions and employments after his term. For example, within one year after the end of his function, he cannot be employed by or otherwise engaged with persons to whom he gave state aid or other advantage within last two years before the end of his function. See Art. 5 para 2 of Constitutional Act on Protection of Public Interest.

${ }^{26}$ See Articles 9-11 of Constitutional Act on Protection of Public Interest. 
Republic and who is electable to the parliament may be appointed to the office. ${ }^{27}$ Nevertheless, the laconic legal wording does not necessary lead to weak management of the AMO. The current head of the AMO is an educated lawyer with more than ten years of practice before he was appointed to the office. ${ }^{28}$ There have been questions about his experience with competition law, however, Mr. Menyhart claimed that he had been working for Transpetrol ${ }^{29}$ as a person responsible for its legal department where he had dealt with competition questions as well (Kováč, 2016a).

Considering the great discretion of the government in the nomination process, it must be concluded that de iure independence is insufficient at this point. Similarly, both political and functional independence is not guaranteed as there are only a few rules precluding a possible conflict of interest. ${ }^{30}$ This shall not be undermined by the fact that the current head of the AMO appears to be a competent person.

Regarding other criteria related to independence and to the head of the NCA, it is positive that the term of the presidency of the AMO is five years, a firmly set period of time that is longer than the term of the government, which is four years. Section 15 of the Act on Competition allows re-appointment of the same person for the position of the president of the AMO. There may be only one re-appointment, that is, the same person may be the president of the AMO only for two consecutive terms. The limited number of these consecutive re-appointments is a guarantee for independence (Blažo, 2012, p. 100). However, re-appointment as such decreases the level of independence of the AMO due to the fact that the government may require a person who is in charge of the AMO to follow its instructions, otherwise the person will not be re-elected.

Despite the possible influence of the government which may be done through re-election, during a particular term, the president of the AMO may fulfil his tasks independently from the government. The government does not have powers to threaten him with removal from office, since the president of the AMO is removed from office by the President of the Slovak Republic in very specific cases only. The reasons for removal are as follows:

27 This flows from Section 15 para 2 of Act on Competition.

28 The curriculum vitae of the president of the AMO is available on the website of the AMO. AMO: Rada úradu. Retrieved from: https://www.antimon.gov.sk/rada-uradu/ (30.06.2019).

29 Transpetrol, a.s. is a company operating crude oil pipeline network in Slovakia in full ownership of the Slovak Republic. TRANSPETROL: Predstavenie. Retrieved from: http://www. transpetrol.sk/predstavenie/ (30.06.2019).

${ }^{30}$ In relation to Constitutional Act on Protection of Public Interest, it shall be noted that this act is rather formalistic and, therefore, cannot prevent engagement with business activities. Due to the limited scope of this paper, we will not deal with conflict of interest in further detail. 
(i) he was effectively convicted for an intentional crime or for a negligent crime which was in direct connection with the exercise of his function;

(ii) he was effectively deprived of his legal capacity to act;

(iii) he commenced a function which is incompatible with the function of president of the AMO. ${ }^{31}$

Another important element of independence is the internal design of the institution. The Act on Competition does not regulate this exhaustively. What is laid down in the legislation is that, apart from the president of the AMO, there are also two other bodies: vice-president of the AMO and the Council of the Authority. Looking beyond the Act on Competition itself, we may observe that the organisational structure of the AMO is quite complex. ${ }^{32}$ The vice-president of the AMO is the chief of the Division of Computer Science and Forensic Activities; Division of Abuse of Dominant Position and of Vertical Agreements; Cartel Division; and Mergers Division. The president of the AMO is in charge of the Division of State Aid; Division for Legislative-Legal Affairs and of Foreign Affairs; Division for the Second-Instance Procedure; Division of Audit and other divisions related to internal affairs. ${ }^{33}$

It flows from the organisation of the AMO that the vice-president of the AMO has a very important position within the authority. He/she is the chief of the first-instance procedure, as he/she is the person who signs the first-instance decisions of the AMO. ${ }^{34}$ Similarly, he/she is the person who executes authorisations to conduct an inspection, when the inspection is conducted during the first-instance procedure. ${ }^{35}$ The vice-president of the AMO is nominated by the president of the AMO and appointed to this function by the government. Similar to the situation with the president of the AMO, there is a lack of requirements on professional skills or experience applicable to the vice-resident of the AMO. Therefore, political influence, or influence from regulated subjects, cannot be excluded. ${ }^{36}$

31 Apart from the reasons for removal mentioned here, the function of the president of the AMO ends (i) upon expiration of the term for which he was appointed to the function; (ii) in case he retires from the office; (iii) in case of his death. See Section 16 of Act on Competition.

32 AMO: Organisational structure of the AMO after 1st February 2019. Retrieved from: https://www.antimon.gov.sk/data/att/2021.pdf (07.06.2019).

33 Apart from these divisions, there is General Secretary of Personal Office, who is in charge of HR affairs and economic and administrative affairs.

${ }^{34}$ See Section 15 para 3 of Act on Competition.

35 See Section 22a para 2 of Act on Competition.

36 Pursuant to the wording of Art. 2 para 1 of Constitutional Act on Protection of Public Interest, which regulates the personal scope of this Constitutional Act, it covers the heads of central authorities of state administration, such as the AMO, however, it is not clear whether vice-heads are covered to. A strict grammatical interpretation would lead to a negative answer. 
Zooming in on the current vice-president of the AMO, Mr. Boris Gregor, it is suggested that he was nominated to his previous position in Bratislavská vodárenská spoločnost', a.s. (Bratislava Water Company) ${ }^{37}$ by the political party Most-Híd mentioned above. To the function of the vice-president of the AMO, he was nominated for the last six months of Mr. Menyhar's first term in the office. Mr. Menyhart claimed that it was fairly difficult to find a suitable person for six months only, as Mr. Menyhart was not sure whether he would be re-appointed for the position. ${ }^{38}$ Therefore, the lack of competition law experience was to be compensated by the fact that Mr. Gregor came from a regulated field ${ }^{39}$ (Kováč, 2016a). Nevertheless, the fact remains that, after Mr. Gregor was appointed to the office, several employees resigned from their position, including the chief of the Cartel Division (Kováč, 2016). The real motivation behind their departures from the AMO remains, according to publicly available information, uncertain. There are rumours about different opinions on the necessity to conduct inspections between Mr. Gregor and the former chief of the Cartel Division. Nevertheless, the fact remains that inspections have been conducted after the personal change in the office of the vice-president of the AMO. ${ }^{40}$

When it comes to the second instance procedure, this is done by the Council of the Authority (hereinafter: Council). The Council consists of the president of the Council, who is also the president of the AMO, and six other members. ${ }^{41}$ The other members of the Council cannot be employees of the AMO. ${ }^{42}$ It is very positive that the appeal procedure is held by persons who are not involved in the first instance procedure. The division of the roles between the president of the AMO and the vice-president of the AMO must be appreciated. Furthermore, it is also apt that the Council acts as a collective body. The level of independence is always higher when decisions are not taken by one person only (Zemanovičová, 2017, p. 50).

However, there is still room for improvement when it comes to the independence of the Council. First, the other members of the Council are

37 Bratislavská vodárenská spoločnosé, a. s., operates water mains and sewer networks in western part of Slovakia, including the capital city. Bratislavská vodárenská spoločnost́: Basic information. Retrieved from: http://www.bvsas.sk/en/about-us/basic-information/ (30.06.2019).

38 Eventually, Mr. Menyhart was re-appointed to the office.

39 Public water mains and sewer networks are regulated by the Regulatory Office for Network Industries. Úrad pre reguláciu siełových odvetví: The Office. Retrieved from: http:// www.urso.gov.sk/?q=node/199\&language =en (30.06.2019).

40 See, for example, the Annual Report of the AMO for the year 2018, pp. 26, 31. AMO: Výročné správy. Retrieved from: https://www.antimon.gov.sk/vyrocne-spravy/ (30.06.2019).

41 See Section 18 para 1 of Act on Competition.

42 See Section 18 para 2 of Act on Competition. 
nominated by the president of the AMO and appointed by the government. ${ }^{43}$ We may argue that more persons might have been recognised by the Act on Competition to have the right to nominate other members of the Council. Moreover, the appointment by the government only confirms the already strong position of the government. Political independence is, hence, not guaranteed (rather, it is the opposite). Second, although there are certain requirements for the other members of the Council, these may be characterised as insufficient. Pursuant to Section 19 para. 2 of the Act on Competition, these requirements are: citizenship of the Slovak Republic, university degree, legal capacity, and clean criminal record. Paragraph 3 of the same section specifies that at least two members of the Council must be lawyers and at least two members must be economists. ${ }^{44}$ It may be claimed that all members of the Council should be either lawyers or economists (or other profession related to the application of competition rules), and, more importantly, that these persons should have some level of experience with competition law. Nowadays, all members of the Council have a university degree, but expertise in competition law is difficult to assess from their publicly available CVs. ${ }^{45}$ Third, although there are positive features of the Council's structure, its decisions are prepared by the Division for the Second-Instance Procedure. ${ }^{46}$ It is questionable to what an extent is the Division for the Second-Instance Procedure separate from divisions dealing with cases in the first-instance. ${ }^{47}$

Regarding staff and funds of the AMO, it is quite difficult to assess their sufficiency. It is positive that the AMO has its own chapter within the State budget, therefore, it can deal with its own resources. As suggested by Zemanovičová and Vašáková, the stability of the budget over a longer period of time suggests a higher level of independence (2016, p. 2501). As it flows from the table below, the revenues of the AMO have been stable. However, it remains questionable whether they have been set on a sufficient level, and whether they should not be increasing at least in relation to the inflation rate.

43 See Section 18 para 3 of Act on Competition.

44 It is quite amusing that the wording of Act on Competition does not require these to be different persons. Therefore, virtually, it is possible that there are only two persons who have both, Master degree from law and Master degree from economics; and the remaining five members including the president of the Council, may be for example, ethnologists.

45 AMO: Rada úradu. Retrieved from: https://www.antimon.gov.sk/rada-uradu/ (30.06.2019).

46 AMO: Organisational structure of the AMO after 1st February 2019. Retrieved from: https://www.antimon.gov.sk/data/att/2021.pdf (07.06.2019).

${ }_{47}$ Naturally, the fact that the Division for the Second-Instance Procedure is responsible to the president of the AMO, whereas "first-instance divisions" are responsible to the vice-president of the AMO, no firewall seems to be created. 


\begin{tabular}{|c|c|}
\hline Act on State Budget for the particular year & $\begin{array}{c}\text { Revenues of the } \\
\text { budgetary chapter } \\
\text { of the AMO }\end{array}$ \\
\hline Act No. 370/2018 on State Budget for the year 2019, Attachment No. 2 & $200000 \mathrm{EUR}$ \\
\hline Act No. 333/2017 on State Budget for the year 2018, Attachment No. 2 & $200000 \mathrm{EUR}$ \\
\hline Act No. 357/2016 on State Budget for the year 2017, Attachment No. 2 & $200000 \mathrm{EUR}$ \\
\hline Act No. 411/2015 on State Budget for the year 2019, Attachment No. 2 & $200000 \mathrm{EUR}$ \\
\hline Act No. 385/2014 on State Budget for the year 2019, Attachment No. 2 & $200000 \mathrm{EUR}$ \\
\hline
\end{tabular}

Source: author.

\section{Independence of National Competition Authorities in the light of Directive 2019/1}

It may be derived from the previous two sections that, firstly, independence is important and it can be affected by various factors and, secondly, that there is still room for improvement when it comes to the independence of the AMO. The question now is: is this problem solved by Directive 2019/1?

\section{The requirements pursuant to Directive 2019/1}

A room for improvement of the independence of NCAs was identified before Directive 2019/1 was adopted (Sinclair, 2017, p. 626). We may start our analysis with the very beginning of Directive 219/1. Recital 3 of Directive 2019/1 reads as follows:

Article 3(1) of [Regulation 1/2003] obliges NCAs [...] to apply Articles 101 and 102 TFEU [...]. Therefore, this Directive, the objective of which is to ensure that NCAs have the guarantees of independence, resources, and enforcement and fining powers necessary to apply Articles 101 and 102 TFEU effectively, [...]. [In] cases of parallel application of national competition law and Union law, it is essential that the NCAs have the same guarantees of independence, resources, and enforcement and fining powers necessary to ensure that a different outcome is not reached.

At this very point we may observe two different shifts in the regulation of NCAs. The first one is that Directive 2019/1, unlike Regulation 1/2003, does explicitly require NCAs to be independent. This requirement has, until the implementation of Directive 2019/1, been derived from EU procedural rules on competition law enforcement by NCAs only implicitly. It is interesting 
to note that this implicit requirement for independence is confirmed by the wording of Recital 5 of Directive 2019/1:

National law prevents many NCAs from having the necessary guarantees of independence, resources, and enforcement and fining powers to be able to enforce Union competition rules effectively. This undermines their ability to effectively apply Articles 101 and 102 TFEU and to apply national competition law in parallel to Articles 101 and 102 TFEU [...].

Therefore, the requirement contained in Article 35 of Regulation $1 / 2003$ to design NCAs so as to ensure that the provisions of Regulation $1 / 2003$ are effectively complied with, indeed comprised the requirement for independence. ${ }^{48}$

Second, Directive 2019/1 diminishes the institutional autonomy of the Member States to a certain extent. The principle of institutional autonomy of the Member States is established in EU law (Ottow, 2013, p. 139). It is well known that institutional autonomy has its limits, especially when it comes to the enforcement of EU law. However, the abovementioned Recital 3 interferes with the application of national law, in particular when EU law and national law are applied in parallel. Recital 8 then states that

there is a need to put in place fundamental guarantees of independence, adequate financial, human, technical and technological resources and minimum enforcement and fining powers.

Naturally, Directive 2019/1 puts into effect a minimal level of harmonisation; Member States are always entitled to have more extensive guarantees of independence. ${ }^{49}$

Although Articles 4 and 5 appear extensive, they do not contain many hard-core obligations for Member States. Therefore, omitting the provisions which might be considered too broad to be enforceable, we may mainly enumerate the following (more or less concrete) obligations which are imposed on Member States in relation to independence:

i. the Member States shall ensure that staff and decision-making persons are able to perform their duties independently from political and other external influence ${ }^{50}$;

ii. the Member States shall ensure that staff and decision-making persons neither seek nor take any instructions, whether from a public body or

48 Recital 5 of Directive 2019/1 also confirms that failure to provide "necessary guarantees of independence, resources, and enforcement and fining powers" leads either to no enforcement, or to enforcement in a poorly manner.

49 See Recital 10 of Directive 2019/1.

50 See Article 4 para. 2 lit. a) of Directive 2019/1. More details are not provided. 
a private entity; when applying European competition law, however, general policy instructions may be permissible ${ }^{51}$;

iii. the Member States shall ensure that staff and decision-making persons do not, basically, act in a conflict of interest during their term and in a reasonable period after leaving the NCA at hand ${ }^{52}$;

iv. decision-making persons shall be dismissed only for reasons related to the proper performance of their duties, to the proper exercise of their powers, to not fulfilling the requirements for the performance of their duties, or to being found guilty for a serious misconduct ${ }^{53}$;

v. the appointment procedure of the decision-making bodies shall be clear, transparent and laid down in advance in national law ${ }^{54}$;

vi. NCAs shall have the right to have enforcement priorities ${ }^{55}$;

vii. Member States shall secure sufficient number of qualified staff and sufficient financial, technical and technological resources ${ }^{56}$;

viii. NCAs shall be granted independence in the spending of the allocated budget ${ }^{57}$;

ix. NCAs shall submit periodic reports to a governmental or parliamentary body ${ }^{58}$, including information about the appointments and dismissals of decision-making persons, and information about the resources ${ }^{59}$.

Apart from obligations, Articles 4 and 5 of Directive 2019/1 provides for certain explicit rights of Member States. For example, it is explicitly stated that proportional accountability requirements for NCAs are to be accepted ${ }^{60}$ which are basically the aforementioned report requirements placed on NCAs ${ }^{61}$.

51 See Article 4 para. 2 lit. b) of Directive 2019/1.

52 See Article 4 para. 2 lit. c) of Directive 2019/1 and also Recital 18 of Directive 2019/1. Regarding the scope of this paper, we will not deal with this part in further detail.

${ }_{53}$ See Article 4 para. 3 of Directive 2019/1.

54 See Article 4 para. 4 of Directive 2019/1.

55 See Article 4 para. 5 of Directive 2019/1.

56 See Article 5 para. 1 of Directive 2019/1.

57 See Article 5 para. 3 of Directive 2019/1 and also Recital 25 of Directive 2019/1.

58 It is interesting to point out that reporting obligation is towards a body of government/ parliament of a Member State. Therefore, this wording suggests that annual reports of NCAS should not be handled by the government or the parliament itself, but by a body created by the government or the parliament.

59 See Article 5 para. 4 of Directive 2019/1.

${ }^{60}$ See Article 4 para. 1 of Directive 2019/1. This provision is related to Recital 22 which explains that credibility and legitimacy is enhanced by accountability.

61 See Recital 22 of Directive 2019/1. 


\section{What shall be amended in the Act on Competition?}

After identification of what is actually required by Directive 2019/1, we may now analyse to what extend shall the Act on Competition be amended and, in that manner, to see whether the insufficiencies regarding independence of the AMO are dully addressed by Directive 2019/1.

Independence from political and other external influence is not presented in further detail. Prohibition to seek or receive instructions from third parties is, again, a little bit vague. From the de iure perspective, an explicit prohibition may be incorporated into the Act on Competition; however, to secure its de facto application will be onerous. Since the government does not have the right to impose instructions onto the AMO in individual cases, this requirement may be already satisfied. When it comes to the dismissal of decision-making persons, it is to be highlighted that they are not legally defined by Directive 2019/1. Therefore, if we consider only the president and the vice-president of the AMO (persons signing decisions of the AMO), this requirement appears to be already satisfied. ${ }^{62}$ Considering the appointment procedure of decision-making persons, Directive 2019/1 does not seem satisfied. ${ }^{63}$ The procedure of nomination and appointment does not seem clear and transparent, as this role is mainly played by the government, without the necessity of a public hearing or a justification of the government's choice. However, since Article 4 para. 4 of Directive 2019/1 does not provide for more details, not even in a demonstrative manner, it is questionable what is required by this provision in practice. ${ }^{64}$

Prioritisation of enforcement is very important in order to create the possibility for NCAs to focus on a particular competition law issues or on particular sectors. The AMO uses prioritisation already ${ }^{65}$, although an explicit provision on the possibility to prioritise may be inserted into the Act on Competition.

Regarding the requirement for sufficient personal, financial and technical background of NCAs, this requirement is not very specific either. There is an attempt for further specification in para. 2 of Article 5, however, the wording therein is rather general and not detailed. For the sake of completeness,

62 If we consider that the other members of Council are also decision-making persons, the dismissal requirements of Directive 2019/1 are also fulfilled pursuant to Section 21 para 3 of Act on Competition.

63 In relation to the other members of Council, appointment procedure is more clear, however, still no public hearing or official justification takes place.

64 No more details are provided by Recital 17 of Directive 2019/1 either.

65 See: AMO: The plan of main tasks. Retrieved from: https://www.antimon.gov.sk/data/ files/1047_plan-hlavnych-uloh-pmu-sr-2019.pdf (09.06.2019). 
Recital 17 of Directive 2019/1 specifies that fines should not be directly used for the direct financing for NCAs. Therefore, it is well possible that the AMO fulfils the requirements even without an amendment of the Act on Competition. The AMO disposes of its own chapter within the State budget and, therefore, it is allowed to spend its allocated finances.

In relation to periodical reporting, the AMO shall submit a report about its activities to the government. Although Article 5 para. 4 of Directive 2019/1 requires reporting to a governmental or parliamentary body, it is assumed that no substantial amendment of the current procedure will be required. The government may easily create a committee to which the report will be submitted.

\section{Conclusion}

Independence of regulatory bodies is always a tricky issue. How is it possible to set the criteria in a way that would safeguard independence from both businesses and politicians? To set such criteria by way of a directive, when we need to safeguard the institutional autonomy of the Member States, is even trickier. However, it was not the purpose of this paper to present a perfect wording of an act of law or of a directive in relation to independence. The very purpose of this paper was to see whether there are some independence issues of a chosen NCA, what they might be and whether they are properly addressed by Directive 2019/1.

The answers to these questions are, first, that there are independence issues regarding the AMO indeed. De iure independence has room for improvement, let alone its de facto independence. Are these solved by Directive 2019/1? The answer is in the affirmative, but only partially. There are still issues which might stay unsolved, even after implementation of Directive 2019/1. First, thenomination and appointment process of the president of the AMO, vice-president of the AMO and of other members of the Council shall be clear and transparent, however, it is not very clear and transparent what does this require in practice. The problematic issue of re-election to the position of the president of the NCA is not addressed by Directive 2019/1 either. Second, as regards the internal design, no collective body for decision-making is required by Directive 2019/1. Third, the requirements in relation to staff and financial resources, there is a threat that the wording of Directive 2019/1 is not sufficient to trigger a real improvement of the financing of the AMO. Therefore, the paper shows that there are still issues related to the independence of NCAs which remain unresolved by Directive 2019/1. 


\section{Literature}

Alves, S., Capiau, J. and Sinclair, A. (2015). Principles for the Independence of Competition Authorities. Competition Law International 11(1), 13-27.

Black, J. (2012). Calling Regulators to Account: Challenges, Capacities and Prospects. LSE Legal Studies Working Paper, 2012(15), 1-38. Available at SSRN: http://ssrn.com/ abstract $=2160220$ or http://dx.doi.org/10.2139/ssrn.2160220.

Blažo, O. (2012). Tretia čast'. Úrad. In: Kalesná K., Blažo O., Zákon o ochrane hospodárskej sútaže. Komentár (pp. 95-104). Praha: C.H. Beck.

Comtois, S., and de Graaf, K. J. (Eds.) (2013). On Judicial and Quasi-Judicial Independence. (Governance \& Recht; No. 7). Den Haag: Eleven International Publishing.

Craig, P. and de Búrca, G. (2015). EU Law. Text, Cases and Materials. 6th ed. Oxford: Oxford University Press.

Cseres, K.J. (2013). Integrate or Separate. Institutional Design for the Enforcement of Competition Law and Consumer Law. Amsterdam Law School Legal Studies Research Paper, 2013(03), 1-51. Available at SSRN: http://ssrn.com/abstract=2200908.

Ezarchi, A. (2016). EU Competition Law. An Analitical Guide to the Leading Cases. 5th ed. Oxford: Hart Publishing.

Jones, A. and Sufrin B. (2016). EU Competition Law. Text, Cases and Materials. 6th ed. Oxford: Oxford University Press.

Kalesná, K. (2012). Právna úprava ochrany hospodárskej sútaže. In: Kalesná K., Blažo O., Zákon o ochrane hospodárskej sútaže. Komentár (pp. 4-7). Praha: C.H. Beck.

Kalesná, K. (2018). Bude fungovat súkromnoprávne vymáhanie sútažného práva? Právny obzor, 101(1), p. 54-61.

Kováč, J. (2016). Protimonopolný úrad bude menej hrýzṫ. Trend, 23 September. Available at: https:/www.etrend.sk/trend-archiv/rok-2016/cislo-38/protimonopolny-urad-budemenej-hryzt.html.

Kováč, J. (2016a). Dosadil šéfa PMÚ oligarcha Czucz? „Nekomentujem, možno bol pri tom,“ priznáva. Trend, 29 September. Available at: https://www.etrend.sk/ekonomika/ dosadil-sefa-pmu-oligarcha-czucz-nekomentujem-mozno-bol-pritom.html.

Małobęcka-Szwast, I. (2018). The Appointment and Dismissal Procedure of the Polish NCA in the Light of EU and International Independence Standards. Wroclaw Review of Law, Administration \& Economics, 7(2). https://doi.org/10.1515/wrlae-2018-0015.

Ottová, E. (2006). Teória práva. 2nd ed. Šamorín: Heuréka.

Ottow, A. (2013). The different levels of protection of national supervisors' independence in the European landscape. In: Comtois S. and de Graaf, K. (eds.), On judicial and quasi-judicial Independence (pp. 139-155). The Hague: Eleven International Publishing.

Pace, L.F. (2015). Decentralised Aplication. In: Tosato, G.L., Bellodi L. (eds.)., EU Competition Law. Volume I Procedure Antitrust-Mergers-State Aid (pp. 247-277). 2nd ed. Deventer: Claeys \& Casteels Law Publishers.

Patakyová, M.T. (2019). Ludskoprávne aspekty hospodárskej sútaže. Antitrust z pohladu ludských práv. 1st ed. Bratislava: Wolters Kluwer.

Sinclair, A. (2017). Proposal for a Directive to Empower National Competition Authorities to be More Effective Enforcers (ECN+). Journal of European Competition Law \& Practice, 8(10), pp. 625-633. 
Van de Gronden J. W. and de Vries S. A. (2006). Independent competition authorities in the EU. Utrecht Law Review, 2(1), 32-66, https://doi.org/10.18352/ulr.16.

Whish, R. and Bailey D. (2012). Competition Law.7th ed. Oxford: Oxford University Press.

Winter, H. (2013). Regulatory Enforcement in the Netherlands: Struggling with Independence. In: Comtois S. and de Graaf, K. (eds.), On judicial and quasi-judicial Independence, (pp. 157-166). The Hague: Eleven International Publishing.

Zemanovičová, D. (2017). Protimonopolný úrad. In Patakyová M. (ed.), Efektívnost' právnej úpravy ochrany hospodárskej sútaže - Návrhy de lege ferenda. Zborník konferencie (pp. 48-54). Bratislava: Univerzita Komenského v Bratislave, Právnická fakulta. 